UDC

821.111(73).09-1 Pand E.

John R O Gery

University of New Orleans, USA

\title{
"THE THOUGHT OF WHAT AMERICA": EZRA POUND'S STRANGE OPTIMISM
}

\begin{abstract}
Through a reconsideration of Ezra Pound's early poem "Cantico del Sole" (1918), an apparently satiric look at American culture in the early twentieth century, this essay argues how the poem, in fact, expresses some of the tenets of Pound's more radical hopes for American culture, both in his unorthodox critiques of the 1930s in ABC of Reading, Jefferson and/or Mussolini, and Guide to Kulchur and, more significantly, in his epic poem, The Cantos. The essay contends that, despite Pound's controversial economic and political views in his prose (positions which contributed to his arrest for treason in 1945), he is characteristically optimistic about the potential for American culture. Behind his flamboyant style, his selfdestructive allegiance to Mussolini, and his complex poetics, Pound anticipated and even initiated the multicultural imperative that by the end of the century emerged as an essential component of American literature.
\end{abstract}

Key words: Ezra Pound, early poetry, satire attitude, radical hopes, epic poems, The Cantos, optimistic views, multicultural imperative

Cantico del Sole

(From Instigations)

The thought of what America would be like

If the Classics had a wide circulation

Troubles my sleep,

The thought of what America,

The thought of what America,

The thought of what America would be like 
If the Classics had a wide circulation

Troubles my sleep.

Nunc dimittis, now lettest thou thy servant,

Now lettest thou thy servant

Depart in peace.

The thought of what America,

The thought of what America,

The thought of what America would be like

If the Classics had a wide circulation ...

Oh well!

It trouble s my sleep.

(Pound 1990: 182)

Besides having the possible distinction of being Ezra Pound's most accessible, least opaque, and ostensibly least profound poem, "Cantico del Sole" also enjoys the seeming advantage of needing no explication about its sentiments. Is it not obvious that, as a self-exiled poet living in England at the time (191718), Pound is bemoaning the lack of "culture" in his native country, mocking his ordinary fellow Americans for their backwoods sensibility, deprived education, and barren provincialism at the start of the twentieth century? After all, this is the same poet who two years earlier wrote "LHomme Moyen Sensual" (in imitation of Lord Byron's attack on British letters, "English Bards and Scotch Reviewers"), a 242-line poem in rhyming couplets which echoes the satirist H.L. Mencken's acerbic debunking of American culture with such lines as, "The constitution of our land, O Socrates,/ Was made to incubate such mediocrities,/ These and a taste in books that's grown perennial/ And antedates the Philadelphia centennial (Pound 1990: 257)". In another poem as equally unsubtle, "The Rest," published even earlier (1913), Pound the expatriot urges his fellow American artists, those "helpless few in my country" and those "of the finer sense/ Broken against false knowledge/.../ Hated, shut in, mistrusted", to take heart in his own flight from his homeland, when he reassures them, "I have weathered the storm,/ I have beaten out my exile (Pound 1990: 93-94)".

Yet despite the precedent of these and other early Pound poems that clearly ridicule the cultural consciousness in the U.S. at the time, it may be that the full import of "Cantico del Sole" is not so self-evident as it seems. ${ }^{1}$

1 With appreciation to Mary de Rachewiltz for instigating the ideas of this essay and to Herbert Richardson for inviting its initial presentation. 
As K.K. Ruthven reports, its original publication in the March 1918 issue of the British journal, Little Review, accompanied a short polemical essay Pound wrote in response to the U.S. postal authority banning the import of the October 1917 issue of the same journal, mainly because it contained a scandalous short story by Wyndham Lewis entitled, "Cantelman's SpringMate"; the Little Review's editor, Margaret Anderson, fought the post office's decision in court and won her case. But Pound objected to the legal argument used to defend the journal, which maintained the artistic legitimacy of Lewis's story on the basis of its being a "classic", a term which Pound saw the court defining as, essentially, having "the sanction of age and fame and USUALLY APPEAL TO A COMPARATIVELY LIMITED NUMBER OF READERS (Ruthven 1969: 48)". What most irritated Pound was the contradiction inherent in the assumption that, by nature, the "classics" (or for Pound, those "books which in the beginning lifted mankind from savagery, and which from A.D. 1400 have gradually redeemed us from the darkness of medievalism") have little social appeal, therein posing no serious threat to the public well-being. But in his commentary on the case, Pound invites his "gentle reader" to imagine the classics being "read by the millions who now consume Mr. Hearst and the Lady's Home Journal!!!!!! (Ruthven 1969: 48)". What then might be their impact if they truly had a broad readership, he wonders.

Indeed, as Pound's daughter, Mary de Rachewiltz, has suggested, in this ditty (if we can call it that) Pound is actually thinking not of the popular conception, but of his own notion of the classics, an impression shared, in fact, by many other classicists - namely, of the scurrilous, erotic or ribald (if not downright pornographic) subject matter of many of the works of poets such as Sappho and others from the Greek Anthology, as well the Roman poets Catullus, Ovid, and Sextus Propertius, whose poems Pound had rendered into English versions. In other words, "Cantico del Sole", in De Rachewiltz's view, ironically speculates not on the civilizing effect of classical literature, but on the rampant epidemic of sexual promiscuity that might well result in the puritanical U.S., "if the Classics had a wide circulation." Read this way, Pound's poem derides both the repressive social morality and the provincial snobbery of those Americans (such as the judge in the Little Review case) who assume that classics offer nothing but "high" culture for an elite who entirely miss the point of their meretricious nature. In short, were the classics to enjoy a "wide circulation", which the judge in the Little Review case obviously assumed they never would and never 
could, who knows what kind of licentious behavior might unleash itself from sea to shining sea.

The poem's title, "Cantico del Sole", or "Canticle of the Sun", alludes to a poem of the same name by St. Francis of Assisi, a poem Pound praises in his 1910 lecture series, The Spirit of Romance, as the "most beautiful" example of the sacred poetry of its age, in which St. Francis, "that "little sheep of God[,]' speaks to the glory of the Father Eternal in a free, unrhymed verse with a rhythm strong as the words (Pound 1968: 101)". In his parodic version, Pound imitates the original's untethered free verse in order to indict his countrymen, as well as to distinguish himself from them ("Nunc dimittis, ${ }^{2}$ now lettest thou thy servant,/ Now lettest thou thy servant/ Depart in peace"). As a typically Poundian exercise in style, the poem takes an ancient model and splices it anachronistically with subject matter from a wholly different era; in this case, he attempts to enact "the shorter, simpler form" and "more ecstatic rhythm" of St. Francis's poem that distinguished it from his medieval contemporaries and, in Pound's view, together comprise "the hardest quality of a man's style to counterfeit (Pound: 1968: 103)". Indeed, no less than seven of the poem's seventeen lines begin like a mantra with the same phrase: "The thought of what America," while two other lines ("If the classics had a wide circulation" and "Troubles my sleep") are repeated twice each, leaving little opportunity for anything else. "Oh, well", sighs the speaker in the penultimate line, as though resigned to the poem's incantation as much as to its subject. Like St. Francis, the poem's speaker has seen the illumination of the divine; only, for Pound it is located not in the sun or the works of God, but in the poetry of Catullus, whose light shines not from heaven, but through art and worldly experience.

Nevertheless, if, despite the poem's derisive tone, we entertain for a moment Pound's "troubled sleep" over the potential impact of "the Classics" on a large, untutored populace - especially in relation to his own ambitious revamping of the classical literary canon in his poetry (namely The Cantos), as well as in such critical works as ABC of Reading (1934), Jefferson and/or Mussolini (1936), and Guide to Kulchur (1938) - what he portends about the U.S. in "Cantico del Sole" may be more salient than even its sexual insinuations are. In my view, the poem anticipates Pound's positive vision of American culture for at least three reasons, the first concerning American

\footnotetext{
2 Ruthven identifies the source of "nunc dimittis" ("now lettest thou depart') from Luke 2:29 as taken from the Authorized Version of the Vulgate version of the Bible (Ruthven 1969: 48).
} 
politics, the second American social mores, and the third American cultural identity. So while Pound's satire may appear disdainful of U.S. society at the turn of the twentieth century - for its provincial values, cultural isolation from Europe, and lack of an aesthetics - his own life's project as translator, critic, social commentator, cultural administrator, and epic poet belies this apparently dismissive attitude by virtue of his devotion to inventing a distinctly American model of a cosmopolitanism, interdisciplinary and multicultural in character. Despite Pound's controversial economics and self-destructive politics, especially before and during World War II (which led to his arrest on charges of treason by American forces in Italy in 1945), behind his flamboyant style, his dramatic bravado as a public figure, his steadfast allegiance to Mussolini, and his complex poetics, Pound precipitated the multicultural imperative that has since then emerged as an essential component of American ideology. In the same way that historians maintain that the American "Founding Fathers" wrote into the Declaration of Independence and the U.S. Constitution the fundamental principles which have been systematically invoked on behalf of democratic changes not themselves envisioned by the Founding Fathers - that is, of a civil equality, for instance, that includes not only property owners, but laborers, immigrants, emancipated slaves, Native Americans, and women - Pound, too, expresses an aesthetic vision beyond his immediate focus. Despite his mocking, irascible tone in "Cantico del Sole", he was actively optimistic about the future of American culture. Although his thinking may seem at a glimpse antithetical to a twenty-first century notion of a diverse American culture, he advanced just such a view, and his work has contributed substantially to its prospects for coming about.

Concerning the three implicit reasons to be troubled yet heartened by Pound's lament over the poor circulation of the classics in the U.S., then, (1) to begin, Pound's sense of the place of the classics in modern culture is directly linked to his convictions about political leadership. In other words, together with his dream of a culturally enriched democracy, Pound also imagined an equally enriched political leadership - an ideal, for instance, that problematically led to his enthusiasm for Benito Mussolini's leadership in post-World War I Italy, which he considered comparable to that of Thomas Jefferson in post-revolutionary America. Pound believed each of these men had the character of an artist as well as a statesman, of a philosopher as well as a man of action, although he attributed to each a very different method. Note, for instance, how in 
Jefferson and/or Mussolini Pound contrasts the two men's ways of solving problems:

The secret of The Duce is possibly the capacity to pick out the element of immediate and major importance in any tangle; or, in the case of a man, to go straight to the centre, for the fellow's major interest. "Why do you want to put your ideas in order?"

Jefferson was all over the shop, discursive, interested in everything; to such an extent that he even wrote a long rambling essay on metrics. He was trying to set up a civilization in the wilderness, he measured the Maison Carree, sent over Houdin to America, and thought it would be better not to sculp [sic] Washington in a fancy dress costume (Pound 1936: 66).

Here Il Duce gets praised for being a kind of Imagist poet, one able to extract the salient detail and grasp its importance, ${ }^{3}$ whereas Jefferson is granted the character of the epic poet, inclusive and expansive in his vision. But the problem with this comparison, as Tim Redman astutely observes, concerns the "difficulty...of Pound's claim that political actions should be judged by aesthetic criteria": "Pound insists that no estimate of Mussolini is valid unless it treats him as an artist.... Thus Pound allowed himself to dismiss any apparent contradictions in Mussolini's political philosophy or actions with the excuse that he was an artist and not bound by ordinary rules of consistency. This excuse was doubly convenient, since apart from resolving inconsistencies, it also tended to help Pound convince himself that his political perceptions were correct.... Thus, by a neat shift of ground, Pound became a political authority (Redman 1991: 118)". Such a rhetorical (if not inadvertently solipsistic) move, however enchanting to those outside circles of power, is potentially catastrophic for large or impressionable populations, it almost goes without saying, and Redman's diagnosis of Pound's fatal mistake in assessing the nature of political leadership helps to explain the poet's tragic encounter with the U.S. government after World War II. As Roxanne Preda argues in a reading of Pound's journalistic writings, "it is relatively easy to write that Pound was a fascist and relatively difficult to

\footnotetext{
3 Pound echoes this impression of Mussolini's discernment in Canto 41, when he quotes what Il Duce apparently said to Pound upon meeting him and having been given a copy of Pound's $A$ Draft of XXX Cantos on 30 January 1933: “'Ma questo,'/ said the Boss, 'é divertente./ catching the point before the aesthetes had got there (Pound 1995: 202)". Pound admires Mussolini's apparent insight into particulars, as opposed to abstractions.
} 
declare him a Fascist, bearing in mind that his position was different from the official Mussolinian ideology in the fundamental questions of nation and war (Preda 2001: 184)". In fact, Preda contends, his allegiance to Mussolini was increasingly stretched as the second war approached, particularly on issues of Mussolini's military expansion and the "Fascist vision of the individual" in which a person's interests are seen as subservient to "the higher interests of the nation (Preda 2001: 178)"4; this "integrative stance" is far from that of Pound, who in the 1920s considered the state as "a nuisance and a hidden enemy" and whose enthusiasm for economic reform was largely based on his belief in relieving individuals from the burden of national debt (Preda 2001: 179). However, his loyalty to Mussolini remained steadfast even after Mussolini's death in 1945.

Despite his misreading of Mussolini's politics, though, Pound's comparison of the Italian leader to Jefferson derives from his understanding of American thinkers (from Benjamin Franklin, John Adams, and Jefferson to Henry James and Mencken); it manifests itself, for instance, in his enthusiasm for Jefferson's notion of government as an arbiter of civic progress, epitomized for Pound by Mussolini's cultural program for Italian Fascism. ${ }^{5}$ As a child of the late nineteenth century, Pound had been exposed to the "rugged individualism" that distinguished entrepreneurs such as J.P. Morgan and politicians such as Theodore Roosevelt, ${ }^{6}$ that philosophy which later gave way to the universalist idealism of Woodrow Wilson, ${ }^{7}$ as

${ }^{4}$ Preda writes, "The Fascist vision of the individual was integrative: a person's interests coincided with the ones of his group; the group found expression in the representation by profession in a larger corporation; the interests of the corporations were expressed in the Council of Corporations in collaboration with the state. The central task of the latter was to harmonize the particular interests of the groups to the higher interests of the nation, and see to it that the nation as a whole enjoys respect and prosperity in the international community (Preda 2001: 178)".

5 As Mussolini proclaimed to a group of students at the Academy of Fine Arts in Perugia in October 1926, for instance, "We must simply exploit our cultural heritage. We must create a new heritage to place alongside that of antiquity. We must create a new art, an art of our times: a Fascist art" (Schnapp and Spackman 1990: 235, cited in Paul 2008: 100).

${ }^{6}$ From the notes of a psychiatric interview of Pound in the 1950s at St. Elizabeths Hospital in Washington, D.C., James J. Wilhelm identifies Pound's paternal grandmother, Susan Angevine Loomis Pound, as a major family source of this world view, when Pound is quoted by the psychoanalyst Jerome Kavka as saying, "You could put that grandmother down as no fuss - no fuss about anything. It was my maternal grandmother that had a great deal of influence upon me (Wilhelm 1985: 125)".

7 In 1913, Pound wrote a letter to Wilson, whom he much later called a "traitor president", urging him at the time to remove a tariff on imported books not otherwise available in the U.S., since, 
much as to the White House favoritism of Warren Harding, and prevailed at least into the Herbert Hoover presidency before the Great Depression. Given this background, regardless of the later tyranny of Italian Fascism in particular, Pound condoned Mussolini's regime, at least in part, because he considered it conducive to the social recognition of individuals such as working artists, of the individual's right to assert difference, and of a culture generated through individual resourcefulness (as opposed to the propagandistic management of crowd behavior and education that was to become, in fact, a hallmark of both Mussolini's and Hitler's regimes). Of course, ascribing a libertarian view of individualism to any kind of fascism after Mussolini and Hitler is anomalous, absurd. Nor can Pound's politics be redeemed by his naiveté about totalitarian tactics. But at least we can qualify this aspect of Pound's thought by the subtitle he adds to Jefferson and/or Mussolini: "LIdea Statale/ Fascism as I Have Seen It". In other words, to concentrate primarily on the ideal fascist state in Pound's imagination - more than the one to which he remained tragically loyal, even after its demise and his own thirteen years of incarceration in Washington - may be more helpful in determining his sense of an American ethos.

A further benefit of individualism, in Pound's view, besides its allowing talented individuals to shape social history, is its implicit endorsement of "difference," that is, its encouragement of original ideas and movements, regardless of the dominant trends or conditions surrounding it. Dante, for example, in his own era, fit this model for Pound. What Pound opposes, as his major poem, Hugh Selwyn Mauberley (1919), makes clear, is the "tawdry cheapness" found everywhere "[d]ecreed in the market place", a debased culture in which "[t]he pianola 'replaces'/ Sappho's barbitos", "We choose a knave or eunuch/ To rule over us", and we only read "the classics in paraphrase! (Pound 1990: 186-87)". Still, Pound's advocacy for the creative work of those outside the status quo, beyond their adherence to tradition or patronage, or for the directive to "MAKE IT NEW" (Pound 1995: 265), which in fact he discovers in classical Chinese thought, remains also central to any argument for openness to the ethnic, racial, gender, or other cultural differences of individuals.

he argued, such "books are usually belles letters and serious work which does not much profit the publisher (Heymann 1976: 225, 347n). In "L'Homme Sensual" Pound mocks the president for "show [ing] his taste in his ambassadors" by appointing mediocre writers to diplomatic posts around the world (Pound 1990: 256-57). 
(2) A second reason to take "Cantico del Sole" more seriously than it might first suggest is that, in the same way that Walt Whitman prophesized the twentieth-century expansion of American consciousness in Leaves of Grass, the future Pound's speaker wishes for in his poem has indeed come to pass. That is, the classics now do enjoy a "wide circulation" in the U.S., particularly among the college-educated, albeit if only as "classics in paraphrase" or in translation. With the proliferation of higher education after World War II grew a vast market for textbooks, including anthologies of Greek and Roman literature, for use in general humanities courses. So might we infer from their distribution in the 1950s and 1960s a causal link to the social revolution in the U.S. that followed in the 1960s and 70s? What about the equally rapid proliferation of "toga" parties at college fraternities, celebrated in the National Lampoon films, or the common practice among political activists of citing everyone from Aristophanes to Henry David Thoreau, Cicero to Mahatma Gandhi, to justify acts of civil disobedience on behalf of civil, ethnic, and women's rights, or in opposition to nuclear weapons and the war in Vietnam? Yet accompanying this widespread use of the classics in support of making radical changes in social, sexual, and religious morality has occurred another form of expansion that Pound dreaded even more than the potentially positive change he imagines in "Cantico del Sole" - namely, the growing economic autocracy in the U.S. of money lenders, financial "experts", bankers, and others unconcerned, in Pound's view, with the lives of individuals. For Pound, the bond between literature and economic policy is seamless. In his 1933 essay, "Murder by Capital", for instance, criticizing the failure of capitalist nations to support artists (not to mention millions of others unemployed during the Depression), Pound writes, "Artists are the race's antennae. The effects of social evil show first in the arts. Most social evils are at root economic. I, personally, know of no social evil that cannot be cured, or very largely cured, economically (Pound 1973: 229)".

While the period after World War II may have sparked an unprecedented expansion of higher education in the U.S. that fostered a more broadly literate citizenry, it also witnessed the unfettered growth of capitalist institutions in a manner exactly counter to the principles of culture Pound believes should rule its growth. In Guide to Kulchur, Pound's polemic on twentieth-century aesthetics, he strategically adopts the German term, "Kulchur", almost as though to pronounce it in an uneducated American vernacular ("kul-cha"); the effect is Pound's own deliberately self-styled, 
yet re-invigorated sense of the term. Then in Chapter Two of the first part of his book, he proposes the "New Paideuma", or "New Learning". "I shall use Paideuma", he explains, "for the gristly roots of ideas that are in action (Pound 1938: 58)". Conspicuously, Paideuma does not refer to the Zeitgeist, as we might think of it, namely, that logocentric viewpoint he sees as dominating Western thought, which includes "the atmospheres, the tints of mental air and idées recues, the notions that a great mass of people still hold or half hold from habit, from waning custom (Pound 1938: 58)"; rather, Pound defines Paideuma as his mentor, German anthropologist Leo Frobenius, taught him to use it, "for the tangle or complex of the inrooted ideas of any period (Pound 1938: 57)". Clearly, the enemy of this "tangle or complex" is "Usury", Pound's epithet for the practice of lending money "without regard to production; often without regard to the possibilities of production (Pound 1995: 230)". Usury, or "Usura", with its disregard for the products of labor, other than as quantities in a series of financial transactions and schemes, undermines the very foundation of the Paideuma as a basis for culture, by the ways it pulls up and apart "the gristly roots" from which a civilization springs. Under such an economy, no art "is made to endure and to live with/ but it is made to sell and to sell quickly," writes Pound in Canto 45, "Usura is a murrain, usura/ blunteth the needle in the maid's hand/ and stoppeth the spinner's cunning (Pound 1995: 229)". So while the wide circulation of the classics may create (and in recent history has created) a greater chance for enhancing the individual autonomy Pound championed, as well as for renewing resources for "ideas that are in action", such grand prospects for an enlightened American populace have been countered by an ever-growing potential for the economic oppression of that same populace, ironically threatening the collapse of the individualism Pound cherished even more than the classics.

(3) However, the third, most important reason to regard with more than just bemusement Pound's "thought of what America would be like/ If the Classics had a wide circulation" concerns less a foreboding of doom for American culture than the significant place of the classics in Pound's larger cultural project as a poet - namely, his vision of an international perspective that not only juxtaposes the "gristly roots" of widely divergent societies, literatures, histories, art forms, religious beliefs, politics, economics, and even languages, but presents and re-presents them - by way of Pound's "ideogrammic method" in The Cantos - as a mingling of source texts, concrete imagery, personal experience, literary tropes, and allusions to 
traditions throughout the world, virtually as a reader might find them in their original context. In a strange kinship with America's Founding Fathers (especially Jefferson and Adams, to whom he devoted long stretches of The Cantos), Pound's "multikulchural" impetus fundamentally envisages the same objectives that multiculturalism as a cultural theory has at the start of the twenty-first century. As difficult as it is to determine exactly what the objectives of multiculturalism are, if we try to characterize its premises, Pound (in particular, in both Guide to Kulchur and The Cantos) provides a clear precedent against which to measure what Henry Louis Gates, Jr., calls "the multicultural initiative (Gates 1992, Loose Canons:175)".

Gates defines "multiculturalism" as the "tendency to broaden our educational vistas" on a world "already...fissured by nationality, ethnicity, race, and gender," in a "radical departure" from a long Western tradition of discourse resistant to the "cultural challenges of pluralism"; as opposed to what he considers a "bygone model of monochrome homogeneity" in defining the ethnic, racial, class, and gender identity of groups, Gates advances a more fluid idea of pluralism, one that "sees cultures as porous, dynamic, and interactive, rather than the fixed property of particular ethnic groups (Gates 1992, "Pluralism": 37-38)". Pound's earlier work, it seems to me, explores at least four of the salient tenets of Gates's multiculturalism. (a) Like Gates, Pound supports the study of diverse literary and artistic works from a broad array of ethnic perspectives, as well as in a mixture of languages, genres and disciplines. (b) He endorses the concept of literature itself (of whatever kind) as an important source of a critique of the dominant culture (artists as the antennae of the race, to use Pound's metaphor), even to the extent that he invites "constructive criticism" of his own method and beliefs. ${ }^{8}$ (c) Pound's idea of Paideuma implicitly embraces multicultural debate as a source of social change. And (d), perhaps most significantly, so that even many of Pound's detractors follow his lead in this regard, he proposes a revision of and reinvestment in the fundamental principles of egalitarian thought. But he voices these concerns not merely by proclamation, but by his method as a poet and critic, by his resistance to compromising his individual views for the sake of being assimilated into

\footnotetext{
8 For instance, in Guide to Kulchur, Pound writes, "To the best of my knowledge young [D.G.] Bridson was the only poet to try constructive criticism on my $A B C$ of Reading. He asked why particular authors (naming them) were omitted and whether someone or other couldn't replace something else. This, the careful student will observe, is the kind of answer I asked for" (Pound 1938: 148). For a discussion of Pound's openness to criticism, see Ruthven 1990: 109-13.
} 
mainstream thought and by his didactic pose as a writer. Despite its difficulty, arcane allusions and complex style, Pound's work is not an expression of cultural elitism (a trait for which he is often criticized, nonetheless), but a refusal on the poet's part to patronize his reader. Pound acknowledges the non-logocentrism of his own work, especially of The Cantos, yet in his unwillingness to slow down or break apart his poetry for his reader - that is, by challenging his readers to engage their minds on their own terms, he conveys his respect for the reader's intellect.

One small, but telling instance of a resonant phrase found both in Guide to Kulchur and The Cantos exemplifies, I think, how Pound expresses his multiculturalism less as an ideological argument than through his method. "Pollon d'anthropon iden" ('And of many men he saw'), writes Pound, in both The Cantos and Guide to Kulchur, quoting the third line from Book I of the Odyssey. In its original context, this opening epic trope from Homer translates into English as, "And of many men he saw/ the cities, and knew their mind (Terrell 1980: 59)". More poignantly, the classicist Robert Fitzgerald translates the lines as, "He saw the townlands/ and learned the minds of many distant men (Homer 1)". Notably, when Pound first employs this phrase in Canto 12 (Pound 1995: 54), he uses the transliterated Greek (rather than the original or an English translation), thereby retaining a semblance of the original phrase's sound, oracular rhythm and thematic resonance for an English reader. Yet in the context of the canto itself, the phrase is juxtaposed to a passage about an American entrepreneur Pound knew, Baldy Bacon, thus indirectly linking him to Odysseus as being worldly, self-sufficient, and resourceful (if notoriously so, as was Odysseus) in outwitting others. Elsewhere near the beginning of Guide to Kulchur, Pound invokes the same phrase, but this time in the context of two Chinese characters taken from the Analects of Confucius:

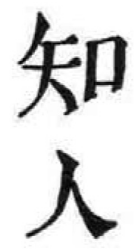

which together form a sentence (or what Pound calls an "ideogram") he then translates as 
Humanity? is to love men.

Knowledge, to know men (Pound 1938: 18).

Not only does this ideogram serve as a hallmark for Pound's theme about the purpose of culture throughout Guide to Kulchur, but later when he returns to it, he repeats, thus confirms, the second sentence of his early translation of the Chinese and then abruptly links it to the same phrase from the Odyssey found in Canto 12:

Knowledge is to know man. Mr. Alexander Pope rubs it a bit too smooth. If you translate him, the proper study for man is anthropology, you get nearer the source of error. Every word ending in -ology in English implies generalities. It implies a shutting off from particulars. It is a thousand miles remove from POLLON D'ANTHROPON IDEN.

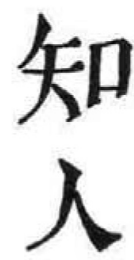

Real knowledge goes into natural man in tidbits (Pound 1938: 98-99).

Typically here, as throughout The Cantos, Pound juxtaposes the Chinese and Greek phrases to insinuate the comparable (though not identical) savvy, even trickery, of three figures simultaneously - the Greek Odysseus, the American Baldy Bacon, and Confucius, each of whose humanity is defined (to use Fitzgerald's translation) by their "learn[ing] the minds of many distant men." But rather than assert this belief as a statement of principle (as, for example, Pope does in "An Essay on Man", to which Pound alludes ${ }^{9}$ ), Pound demonstrates his principle by offering "real knowledge... in tidbits." 10

9 Pound is thinking of these lines from Epistle II of Pope's poem: "Know then thyself, presume not God to scan,/ The proper study of mankind is man" (Pope 1954: 57).

${ }^{10}$ Strangely, however, nowhere in Canto 53 do the two Chinese characters themselves, which Pound juxtaposes to the Greek phrase in Guide to Kulchur, appear. Oddly enough, the only other use of 
While his method of splicing quoted lines, contrasting images, various languages, mythic allusions, personal and historical moments, rhythms, and even tones may seem disruptive, or disorienting, at first, this method works to engage the reader not only in Pound's thought but in its implications by enacting his convictions. Aligning "pollon d'anthropen iden" with the Chinese phrase from Confucius in order to offer a perspective on Pope illustrates Pound's commitment to "ideas into action" as a part of the New Paideuma. In its specificity it also conveys another Confucian principle he deems essential to a vision of a non-Westernized, non-logocentric "Kulchur":

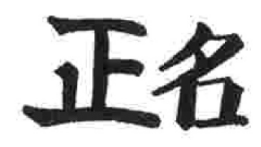

(Pound 1995: 252)

Pronounced "CH'ING MING," meaning "to regulate + the name: to define the correct terms...: a true definition" (Edwards and Vasse 1957: 269), this ideogram was the first Chinese character to appear in The Cantos (Canto 51), at the close of The Fifth Decad of cantos in 1937. Together with the directive of "ideas into action", it speaks to the integrity of the individual identity, precisely defined, as rendered in the fifteenth chapter of the Analects, where (as Pound cites it in Guide to Kulchur) the Chinese sage tells his disciple:

If the terminology be not exact, if it not fit the thing, the governmental instructions will not be explicit, if the instructions aren't clear and the names don't fit, you cannot conduct business properly (Pound 1938: 16). ${ }^{11}$

For Pound, especially in the 1930s, the key to accommodating differences between individuals is to achieve "a clear terminology whereof no part can be mistaken for any other" (Pound 1938: 59), where there

the Greek phrase in The Cantos occurs in abbreviated fashion in all capital letters, as "POLLON IDEN," at the end of Canto 53 (one of Pound's ten cantos derived from ancient Chinese history), when he applies it briefly to the "brain work" of a Taoist philosopher and minister of state named Sou-tsin near the end of the Chou Dynasty in the third century BCE (Pound 1995: 274).

${ }^{11}$ A few pages later, he cites it again, adding, "The ch'ing is used continually against ambiguity (Pound 1938: 21)". 
is minimal misunderstanding in expression, such that (as he states much later), "Every man has the right to have his ideas examined one at a time (Pound 1973: 355)". The gist here is not to privilege ideas or individuals, but to define all persons or principles by an accurate naming of them, in relation to others. ${ }^{12}$

What suffocates Western culture for Pound, and what therefore appeals to him about Eastern thought as well as other particular traditions, is the linear, abstract logocentrism we have inherited from the main current of Greek thought through the Middle Ages, leading to its inevitable hierarchies and closed systems of exchange. Or, "in any case", concludes Pound, "-ologies come out of greek separation and dilettantism. 'Occupy leisure with the arts'. For Kung [Confucius] and co. the arts included riding horses and using the bow and arrow (Pound 1938: 100-1)". Cultural pluralism, or a cultural diversity that is truly inclusive, such as what Gates and other cultural theorists advance in our time, requires not only a precise awareness of widely variant communities (such as the "many men" known by Odysseus), but a ready accommodation of each community, according to its particular ethos in relation to one's own. In fact, as a demonstration of a spirit of inclusiveness, in both his poetry and his prose, Pound freely jumps from one culture to another, one myth to another, one language to another, one genre to another, even one discipline to another - in a graphic display of echoes that inform each other. One of the most telling paradoxes of Pound's work, especially in the style of The Cantos, is how the more heavily he arranges multiple correspondences of imagery, quoted phrases (translated or in their originals), mythic and historic figures, and private memories, the more intimate becomes the poet's unique voice. The more cross-cultural Pound is, the more precisely is he himself.

This is Pound's multiculturalism, then - or at least his expression of cultural pluralism - in praxis. If his writing often frustrates us by its abrupt shifts in subject or tone, its proliferation of unfamiliar terms and traditions, and its challenge to our sense of the function of literature, it is in no small way because of his unyielding determination to offer us the world and his world simultaneously, because of our own resistance to variant styles, and

\footnotetext{
${ }^{12}$ In arguing that the political goal of multiculturalism is more economic than ethnic in nature, the philosopher Richard Rorty has defended the multicultural initiative, at least in academia, as "obsessed not with the suffering but with the 'identity' of the groups that have been shoved around (Rorty 1995: 14)". This is similar to Pound's assertion that the accurate naming of an individual or group is essential to providing that person or group a meaningful place within a community; this is why literature has a crucial role to play in shaping a political economy.
} 
because of the raw edges of his experimental project. Pound had not the historical advantage of witnessing the international exchanges (both good and bad) that by now have enabled us (for better or for worse) to handle even overt cultural differences with relative ease. His abrupt shifts and cross-cultural methodology may not be as unfamiliar to us as we might think, once we recognize our own particular exercising of multicultural thought in our own social and imaginative experiences. ${ }^{13}$

Behind the posturing, the project of Pound's literary and social criticism and the intricate design of The Cantos is precisely to identify the many men and women, distant and near, whom he has encountered - pollon d'anthropon iden - yet to name each individual accurately - ch'ing ming. And even as he invites criticism of his efforts, we would do well also to recognize, beyond the political blunders he made, his contribution to opening cultural vistas and making them new. Such a project ultimately testifies to Pound's abiding optimism, however strangely expressed, for the "post-modern" culture we have inherited from him. Ironically, while Pound does not seem to fit the paradigm of the multiculturalist who, as Gates puts it, "through education... seeks to comprehend the diversity of human culture" and believes that "there is no tolerance without respect - and no respect without knowledge" (Gates 1992, "Pluralism": 37), his conspicuous display of the ideogrammic method throughout the more than eight hundred pages of The Cantos serves as one authentic ur-text for shaping the critical thinking at the heart of any truly cross-cultural vision, in the U.S. or elsewhere. With the American Founding Fathers (and I use that term advisedly, deliberately), it has taken us more than two centuries to realize some of the implications of their thinking on behalf of individual equality and human rights, in order to begin to apply them uniformly across communities. Indeed, the full reach of their thinking is

${ }^{13}$ In his introduction to an anthology of essays on multicultural theory, Charles Lemert makes a similar observation about how international consciousness has evolved in the recent centuries. Contrasting the many horrors of the contemporary world ("war, poverty, human misery, and hunger... alongside a few environmental and other miseries") with technological "wonders" such as mobile telephones and MTV that have developed concurrently, Lemert reflects on the relative social isolation of those Enlightenment thinkers who initially furnished the dominant ideas precedent to, though often critiqued by, contemporary theorists. The conditions of our own world, he suggests, have prepared us to admit cultural diversity into our thinking without question in a manner not even considered by thinkers such as Kant who rarely "gave more than passing thought to the moral, political, or economic powers and rights of those outside their very narrow spheres of social experience (Lemert 1993: 21)". By contrast, Pound's modernist work ruptured traditional Western thought through his internationalist technique and perspective. 
still unknown to us. With Pound, despite his own self-destructive activities during World War II and his "stupid suburban prejudice of anti-Semitism", as he came to denigrate his own behavior late in his life (Ginsberg 8), the relevance of his thinking on cultural diversity and the Dantean reach of his work as an epic poet also remain to be discovered. Ah, yes, "the thought of what America would be like/.../ Oh, well!/ It troubles my sleep."

\section{References}

Edwards, J. H. and William W. Vasse. Annotated Index to the Cantos of Ezra Pound: Cantos I-LXXXIV. Berkeley: University of California Press.

Gates, H. L, Jr. (1992). Loose Canons: Notes on the Culture Wars. New York: Oxford University Press.

Gates, H. L, Jr. (1992). "Pluralism and Its Discontents." Profession 92, 3538.

Ginsberg, A. (1980). Encounters with Ezra Pound. In: Composed on the Tongue: Literary Conversations, 1967-1977 (Donald Allen, ed.). San Francisco: Grey Fox Press, 1-17. (Original work published 1974)

Heymann, D. (1976). Ezra Pound: The Last Rower, a Political Profile. New York: Carol Publishing.

Homer (1963). The Odyssey (Robert Fitzgerald, trans.). New York: Doubleday.

Lemert, Ch. (1993). Social Theory: Its Uses and Pleasure. In: Social Theory: The Multicultural and Classic Readings (Charles Lemert, ed.). Boulder: Westview Press, 1-24.

Paul, C. (2008). Ezra Pound, Alfredo Casella, and the Fascist Cultural Nationalism of the Vivaldi Revival. In: Quaderni di Palazzo Serra 15: Ezra Pound, Language and Personae (Massimo Bacigalupo and William Pratt, eds.). Genoa, Italy: Universita degli Studi di Genova.

Pope, A. (1954). The Poetry of Pope: A Selection (M.H. Abrams, ed.). New York: Appleton-Century-Croft.

Pound, E (1936). Jefferson and/or Mussolini. New York: Liveright. 1970 edition. edition.

(1938). Guide to Kulchur. New York: New Directions. 1968 (1968). The Spirit of Romance. New York, New Directions. 
(1973). Selected Prose, 1909-1965 (William Cookson, ed.). New York: New Directions.

(1990). Personae: The Shorter Poems of Ezra Pound. Revised Edition

(Lea Baechler and A Walton Litz, eds.). New York: New Directions.

(1995). The Cantos of Ezra Pound. New York: New Directions.

Preda, R. (2001). Ezra Pound's (Post)Modern Poetics and Politics: Logocentrism, Language, and Truth. New York: Peter Lang.

Redman, T. (1991). Ezra Pound and Italian Fascism. New York: Cambridge University Press.

Rorty, R. (1995, January). Demonizing the Academy. Harper's, 13-17.

Ruthven, K.K. (1969). A Guide to Ezra Pound's Personae (1926). Berkeley: University of California Press.

(1990). Ezra Pound as Literary Critic. New York: Routledge.

Schnapp, J. and Barbara Spackman (eds.) (1990). Selections from the Great Debate on Fascism and Culture: Cultura Fascista 1926-1927. Stanford Italian Review, 8, 235-72.

Terrell, C. F. (1980). A Companion to The Cantos of Ezra Pound. Berkeley: University of California Press.

Wilhelm, J. J. (1985). The American Roots of Ezra Pound. New York: Garland.

Accepted for publication: October $5^{\text {th }}, 2010$

Џон Р О Гери

\author{
„ПОМИСАО НА ТО ШТА БИ АМЕРИКА“: \\ НЕУОБИЧАЈЕНИ ОПТИМИЗАМ ЕЗРЕ ПАУНДА
}

\title{
Сажетак
}

Кроз поновно разматрање ране поезије Езре Паунда (Ezra Pound) “Cantico del Sol” („Кантико дел сол”, 1918), kоја без сваке сумње представља сатиричну визију америчке културе у првим деценијама XX века, у овом есеју аутор показује како песма заправо изражава нека од Паундових уверења у којима се могу препознати његова оптимистичка очекивања у погледу домета америчке културе. Овај корпус укључује Паундову радикалну критику из четврте деценије XX века у делима као 
што су ABC of Reading, Jefferson and/or Mussolini, i Guide to Kulchur (АВСчиталачке праксе, Џеферсон и Мусолини, и Водич за Калчер), а на још упечатљивији начин овај принцип исказан је у његовој епској песми The Cantos (Kantos). Аутор овог есеја тврди да упркос Паундовим контраверзама, односно економским и политичким погледима које изражава у својој прози (оних који су довели до његовог хапшења 1945. године) Паунд остаје оптимиста у погледу потенцијала америчке културе. Иза његовог китњастог стила, само-деструктивног прихватања Мусолинија и комплексне поетике Паунд је предвидео, чак и у својој поезији изразио неопходност изградње мултикултуларног друштва. Крајем века ова потреба се испољила као један од основних обележја америчке заједнице.

Кључне речи: Езра Паунд, рана поезија, сатира, радикална очекивања, епска песма, Кантос оптимистичка визија, мултикултулатрност као императив 
